\title{
STUDY REGARDING THE POSITIONING OF TRANSILVANIA BANK IN THE RANK SMEs FROM ALBA IULIA
}

\author{
Iulia Iuga ${ }^{1}$ \\ Ruxandra Radoviciu ${ }^{2}$
}

ABSTRACT: Recent changes in the market caused by economic crisis affected the Small and Medium Enterprises. The study helps Transilvania Bank to see the place on the market and the image among Small and Medium Enterprises. Following the predictions made by the small and medium enterprises the bank has the possibility to develop the products and services offered.

Key words: bank, small and medium business, market

JEL codes: M31.

\section{Introduction}

Positioning can be defined as the action to create the offer and the image of a company in such a way that it will create a distinct place in the mind of the clients from the target market (Kotler Ph., 2005, p.396).

The complete positioning of a brand can be defined as proposal of value or value of the brand that consists in the complete combination of advantages on which the brand is positioned (Kotler Ph. Armstrong G., 2008, p.299).

The transformation of the economic environment, adjustments to market changes, knowledge of customer preferences, as well as many other important issues will be known only after conducting a research on the market.

Therefore we considered useful this research carried out among SMEs from the Alba County to verify the degree of concordance between the results obtained around our country and those specific to the city of Alba Iulia.

A further reason in our approach was given by recent changes in the market caused by economic crisis, which affected the Small and Medium Enterprises.

After the type of information resulting from the research is a quantitative one and after place a field research. After the purpose, this research can be considered as being a descriptive one. The information was gathered by conducting research on a one-time on a sample of respondents. The results of this research can be used to develop further marketing strategies and also some recommendations about certain actions of the bank.

\section{Research methodology}

Purpose of the research: potential description and positioning of Transilvania Bank among Small and Medium Enterprises.

General objective: Market assessment for financial and banking services in Alba Iulia.

Specific objectives:

- $\quad$ Measuring the reputation of the banking institutions;

\footnotetext{
${ }^{1}$ Finance and Accounting Department, "1 Decembrie 1918” University of Alba Iulia, 11-13, N. Iorga Street, Alba, iuga_iulia@yahoo.com;

${ }^{2}$ Management - Marketing Department, "1 Decembrie 1918” University of Alba Iulia, 11-13, N. Iorga Street, Alba, ruxandra_rdvc@yahoo.com ;
} 
- $\quad$ Analysis of the general opinion about banks;

- $\quad$ Analysis of banking penetration among Small and Medium Enterprises;

- $\quad$ Evaluation of the satisfaction towards banks;

- $\quad$ Customer segmentation based on benefits expected from the banks;

As research hypothesis were established the following:

- $\quad$ Payment for financial and banking services is favorable;

- $\quad$ Transilvania Bank has the highest reputation among the interviewed persons;

- $\quad$ Transilvania Bank enjoys a high favorability;

- $\quad$ Banking for Small and Medium Enterprises are most demanded on the market;

- $\quad$ Transilvania Bank has the most satisfied customers in relation to its competitors;

- $\quad$ Highest share is held by the Small and Medium Enterprises segment;

Researched collectivity: General collectivity is represented by the total number of small and medium enterprises in the city of Alba Iulia in the end of 2008. Number of active firms in the city is 4675 and almost a half of them, respectively 2203, are small and Medium Enterprises ${ }^{3}$.

The observation unit is represented by small and medium enterprises that benefit from banking services and research unit is the General Manager, the Administrator, Marketing Director, and Economic Director.

Method used to collect the information: In order to answer the research objectives the chosen research method was a face to face interview based on a questionnaire with predefined questions.

Sample size: The sample consists in 300 companies located in Alba Iulia, which is likely to guarantee a result of $95 \%$ with a margin of error of $\pm 5 \%$.

The results of the research were the following:

Regarding the decision-maker within the unit, in firms with over 9 employees the general manager is the person responsible for decisions about financial and banking operations, while in small companies the managing director is the deciding person.

Important changes have occurred in the economic environment in Romania reflected especially in the mood of customers their general state is of pessimism. Almost half of the interviewed staff (41\%) believes that their businesses will going worse than in 2008 and $28 \%$ of respondents were of the opinion that business will be the same. The number of optimistic staff decreased from $38 \%$ by $9 \%$ in 2008 . Respondents don't want to extend their business, $63 \%$ saying they will keep the same activity as now.

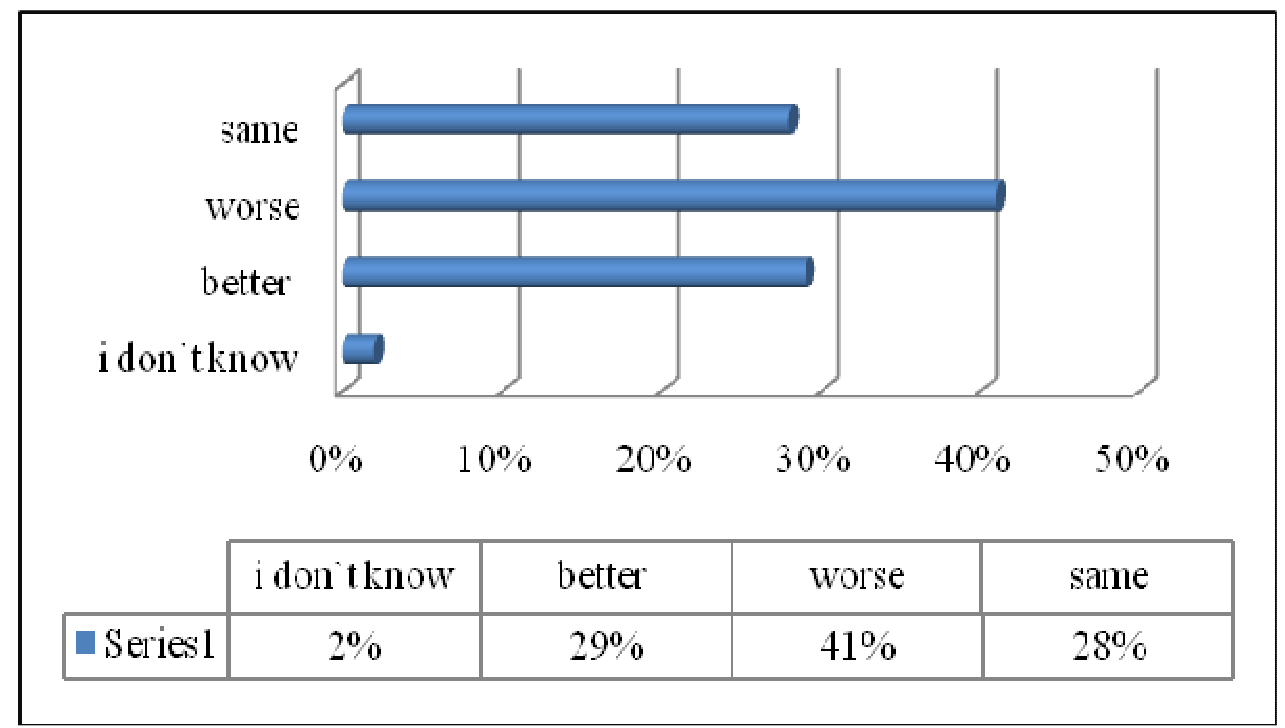

Fig. no. 1. The evolution of business in the view of the interviewed staff for the next 12 months

\footnotetext{
${ }^{3}$ National Institute of Statistics Regional Statistics Alba Iulia
} 
Possible explanations for this state of mind are, "leu" depreciation, economic crisis that made its presence in our country, increased competition etc. In the situation in terms of hired staff things are not very reassuring as well. In companies with over 10 employees, who have different profile of activity, number of employees is possible to drop. Companies with 3-9 employees will retain its staff will make small cuts. This trend is visible from the beginning of the fourth trimester from 2008 for the entire economy, with greater declines in the industry.

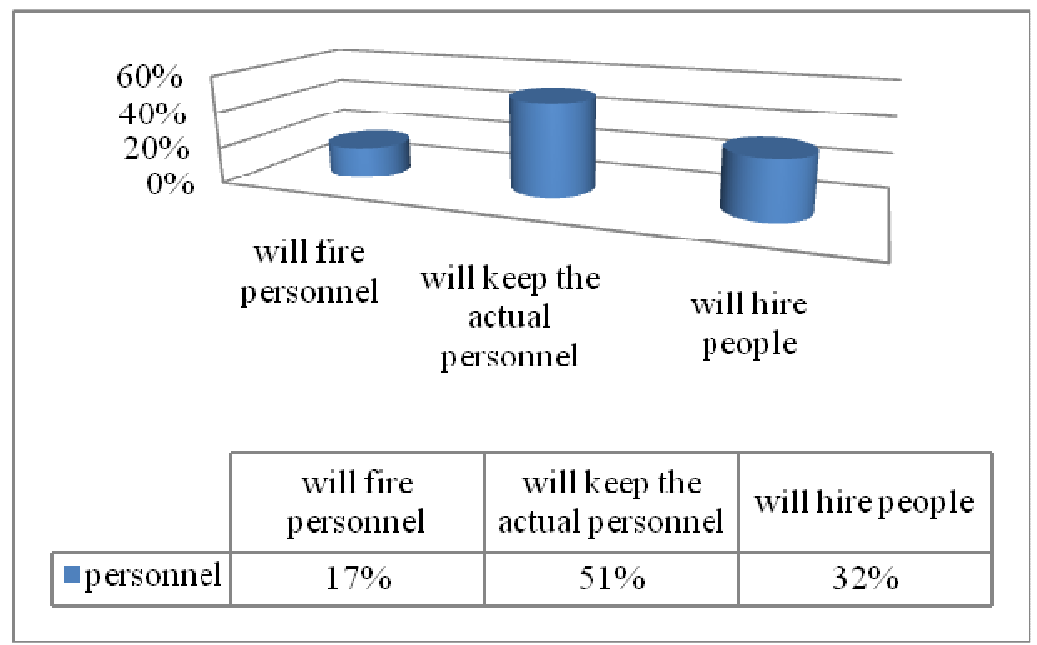

\section{Fig. no. 2. Intentions regarding the companies' personnel for the next 12 months}

Analysis of familiarity vs. suitability was based on the following questions: "I will mention a few names of banks and I ask you to tell me if you know how these banks?"; "What do you thik about each of these banks?". We can say that Transilvania Bank is less favorite than "BRD" and Raiffeisen Bank. Transilvania Bank does not compete with "BCR". Transilvania Bank occupies the fourth position after "BCR", "BRD" and Raiffeisen Bank followed by "BancPost" and "Unicredit". Direct competitors of Transilvania Bank are "BRD", Raiffeisen Bank and "BancPost".

The trend of investment currently remains quite high at a $59 \%$ percent. This can be explained by the fact that now in the middle period of the economic crisis, prices for machinery, cars, land and buildings dropped, and companies seek to take advantage of this situation given that the economic crisis prefigures to end in our country at the end of 2011.

The main reasons customers want to take a loan are the following: 1 . Development; 2 . Long time security (buildings, lands); 3 . Emergency cash injections (for current activity) but the average amount of credit they would like to buy it is 30.000 euros.

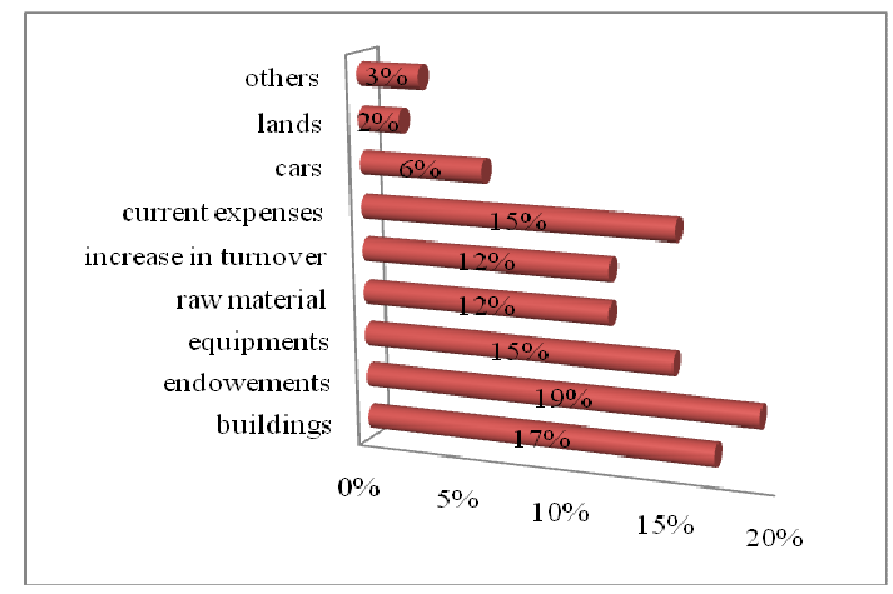

Fig. no. 3. Intentions regarding companies` investments for the next 12 months 
In this case also is given special importance towards the products used by small and medium enterprises, operations of current informing on the account statement (41\%), closely follows the credit (38\%).

In Alba Iulia head of the list of problems encountered in the SME market sites is the lack of order, followed closely by disadvantageous credits, fluctuating legislation, bureaucracy, or discrimination between firms.

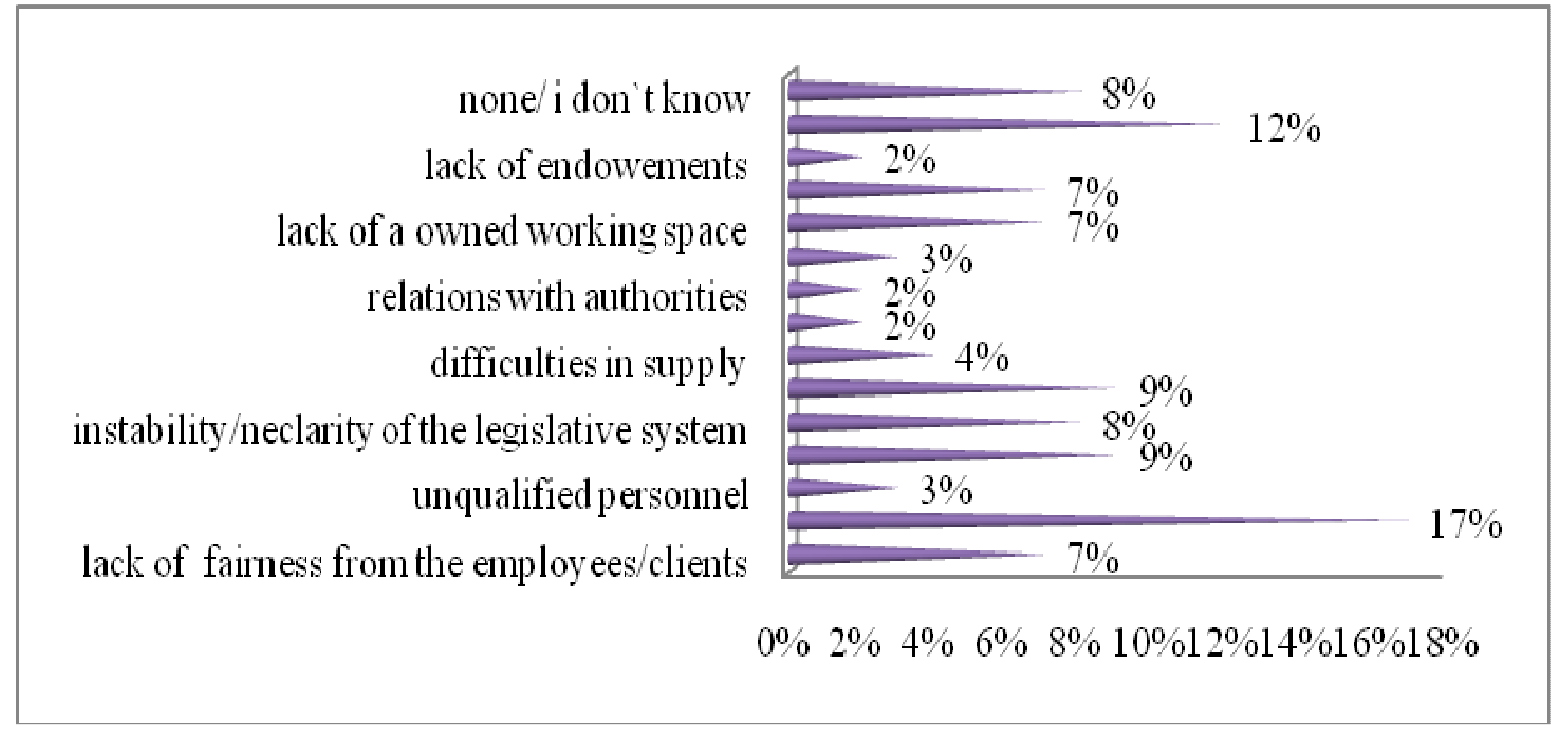

Fig. no. 4. Problems encountered on the market by Small and Medium Enterprises

Some products used by Small and Medium Enterprises can be considered the following:

- Demand for abstracts of account and other information;

- Cash deposits

- Credits

- Documentary operations

- Making payments

- Payment of employees wages into an account

- Internet banking

- Home banking

- Payments and receipts

\section{Conclusions}

Some small and medium businesses have deeply suffered from the effects of the actual economic crisis that affected our country and the Transilvania Bank should help the clients with economic activity to pass the difficulties by offering:

- $\quad$ An action plan that could help the small and medium enterprises;

- $\quad$ Promotional discounts from the commission for loyal clients;

- Information to profitable companies in order to inform them about certain confiscated goods that are sold in an auction;

Should develop new types of credits and credit cards in order to approach new clients;

\section{References}

1. Balaure V., (coord), 2002. Marketing, Uranus Publishing House, Bucharest.

2. Basnoc C., Dardac N., 2002. Banking Management, Economica Publishing House, Bucharest.

3. Cătoiu I., (Coordonator), 2002. Marketing researches, Uranus Publishing House, Bucharest. 
4. Olteanu V., 2005. Financial banking marketing, Ecomar Publishing House, Bucharest.

5. Kotler Ph., 2005. The management of marketing, Teora Publishing House, Bucharest.

6. Kotler Ph., Armstrong G., 2008. The principles of marketing, Teora Publishing House, Bucharest.

7. Odobescu E., 2007. Modern banking marketing, New edition. Sigma, Publishing House, Bucharest.

8. National Institute of Statistics Regional Statistics Alba Iulia, www.insse.ro

9. www.bnr.ro

10. www.bancatransilvania.ro 